\title{
CONTROL MODEL FOR GROUND CREW SCHEDULING PROBLEM AT SMALL AIRPORTS: CASE OF SERBIA
}

\author{
Lena ĐORĐEVIĆ MILUTINOVIĆ ${ }^{*}$, Dragana MAKAJIĆ-NIKOLIĆ ${ }^{2}$, \\ Slobodan ANTIĆ ${ }^{3}$, Marija ŽIVIĆ ${ }^{4}$, Andrej LISEC ${ }^{5}$ \\ 1,2,3,4 Faculty of Organizational Sciences, University of Belgrade, Serbia \\ ${ }^{5}$ Faculty of Logistics, University of Maribor, Slovenia
}

Submitted 11 August 2019; resubmitted 6 March 2020; accepted 29 April 2020

\begin{abstract}
Present-day airline industry is quite a competitive field and crew scheduling represents one of the crucial problems due to significant impact on the airline's cost. The crew scheduling problem is based on the assignment of crew members to operate different tasks of route. The main goal of this paper is to provide an analysis and a solution to one of the biggest problems detected on a small airport in the Serbia - the problem of ground crew scheduling. The paper presents the main characteristics, goals and limitations of a real-life problem identified at this small airport. In order to solve the problem, we developed a dynamic discrete simulation model. The model is developed in a spreadsheet environment of Microsoft Excel. Some of the main limitations found in the development of the model are strong constraints and multiple goals. The model presented in the paper is designed as a useful management tool for smaller airports and is aimed at the improvement of operative processes.
\end{abstract}

Keywords: crew scheduling problem, modelling, air transport, small airport, management, spreadsheets.

\section{Notations}

$a_{j}$ - discrete time unit related to the start of activity $j(j \in N)$;

$b_{j}$ - discrete time unit related to the end of activity $j(j \in N)$;

$e_{i}$ - auxiliary variable related to the end time of the shift for a steward $(i \in S)$;

$J$ - objective function;

$k_{j}$ - activity $j$ category $(j \in N)$;

$k v_{i}$ - steward $i$ category $(i \in S)$;

$N$ - set of activities;

$N D R V$ - the longest work time;

$N K R V$ - the shortest work time;

$N M P$ - minimum duration of break;

$p_{t j}$ - binary parameter related to the beginning of activity $j$ in time period $t(t=1, \ldots, T ; j \in N)$;

$p s_{i}$ - auxiliary variable related to the start of all activities for a steward $i(i \in S)$;

$p z_{i}$ - auxiliary variable related to the end of all activities for a steward $i(i \in S)$;

$S$ - set of available stewards;

$s_{i}$ - auxiliary variable related to the start time of a shift for a steward $i(i \in S)$;
$T$ - finite time horizon;

$t p_{j}-$ activity $j$ duration $(j \in N)$;

$t r_{t j}$ - binary parameter; 1 - activity $j$ in progress in time period $t ; 0$ - otherwise $(t=1, \ldots, T ; j \in N)$;

$x_{i j}$ - binary variable; 1 - steward $i$ realizes activity $j$; 0 - otherwise $(i \in S, j \in N)$;

$z_{t j}$ - binary parameter related to the ending of activity $j$ in time period $t(t=1, \ldots, T ; j \in N)$;

$z a_{i t}$ - binary variable; $1-$ steward $i$ is at the airport in time period $t(t=1, \ldots, T ; i \in S) ; 0$ - otherwise; "ground

crew" - terms steward/stewardess are used interchangeably in this paper;

UDF - user-defined function.

\section{Introduction}

Air transport represents a significant industrial sector, in constant evolution since the late 1950s. According to Kasirzadeh et al. (2017), the importance of this industry is characterized by its own operations, as well as the influence on related industries, such as tourism and aircraft

${ }^{*}$ Corresponding author. E-mail: lena.djordjevic.milutinovic@fon.bg.ac.rs 
manufacturing. Considering the competitiveness of the air traffic industry, the development and implementation of high-level systems of monitoring and control is a necessity. Large aviation centers, such as airports in European capitals, have highly developed monitoring and management systems, that operate in accordance with their numerous needs. However, beside the central ones, there are many small and medium-sized airports (regional or secondary airports) that enable a better connection with different locations, facilitate business and holiday travels and improve the overall air transport efficiency (Pavlin et al. 2007). The scope of services at these airports is often much narrower than at big airports. Consequently, management is not oriented towards processes optimization, the development of specific tools for monitoring and control of operations, and the formulation of global procedures. The functioning of smaller airports is frequently based on employees' expertise and their own experience.

"Constantine the Great" airport in the city of Niš can be classified as one of the smaller airports, while the largest airport in the Serbia is located in its capital - Belgrade. The "Constantine the Great" airport was initially a military airport, transformed into a military-civilian airport, to be used today as a civilian airport. This change additionally affected the organization and control of operations and activities on this airport. The airport became increasingly significant in the South Balkans after 2003. From 2007, in accordance with the development plan 2007-2022, the airport's business operations radically improved. Through collaboration with low-cost carriers and an expanded destinations list, "Constantine the Great" became an important airport for passenger traffic. According to statistics (NCGA 2019), there has been a sharp increase in passenger traffic in the past several years.

The described changes required the development and implementation of control methods and tools. Additionally, in accordance with the increased level of operative processes, the problem of human resources capacity shortage arose. This shortage implies the crew-scheduling problem. Some research shows that after the cost of fuel, which cannot be controlled by the airline, the second highest expense is the crew scheduling cost (Oketch 2013).

The aim of this paper is to develop a model for solving the ground crew scheduling. The start of the modelling process will be to identify the problem parameters. The following step will include the definition of variables, objective function and constraints. In order to solve the problem and facilitate understanding of the scheduling process for employees, authors propose a simulation model implemented in the Microsoft Excel environment. Microsoft Excel is chosen because it is generally accepted in the business world; it is accessible, flexible and easy to use, without formal rules or training required. The developed simulation model is dynamic, flexible, affordable and relatively easy to use.

Starting from this point, the paper is organized as follows. Section 1 addresses the background of the study and describes the ground crew scheduling problem in the airline industry. Section 2 points out some of the main characteristics of the problem and challenges related to crew scheduling at the airport "Constantine the Great". Section 3 presents the mathematical formulation of a discrete time control process corresponding to the ground crew scheduling problem at the airport. In Section 4, the developed model is implemented as a simulation model in a spreadsheet environment of Microsoft Excel. Section 5 includes a sensitivity analysis and a comparative review of numerical results obtained through the simulation. Finally, the last section outlines the conclusions and summary of the above mentioned.

\section{Background and related work}

Human resources represent one of the most important resources in all areas of business. When it comes to services, that importance is even more pronounced. A great deal of human resource management problems in services comes from demand variation. For example, production planning as a result has production quantity. Consequently, the number of employees required for a plan to be fulfilled is based on the normative and process description. However, in the services industry, the varying number of customers directly affects the workload.

The airport, used as an example in this paper, was faced with a significantly increased number of passengers due to collaboration with low-cost carriers. Although this was a great potential for the airport business, it imposed new requirements to the existing infrastructure and organization of the airport (Pavlin et al. 2007; Ivković et al. 2018). Numerous arrivals and departures of airplanes, supporting activities, and possible changes in flight schedules, required improvement in workforce scheduling. This improvement includes scheduling methods and techniques, and their incorporation into the airport information system, as one of the crucial elements for good performance of an airport as a system (Rodič, Baggia 2017).

Many researchers have studied the crew scheduling problem as an attractive and frequently observed problem in transport (Giachetti et al. 2013; Duque et al. 2016; Bach et al. 2016; Zhou et al. 2016; Pour et al. 2018; Wang et al. 2018, Boyer et al. 2018). Scheduling problems in air transport industry refer to aircraft crew and ground crew scheduling. This paper is oriented towards ground crew scheduling and aimed at designing a useful tool for the management of small airports and the improvement of various operative processes.

The planning of airport ground workforce poses a number of challenging optimization problems (Herbers 2005). Crew scheduling problems affect crew operations. The scheduling problem is directed towards the execution of a required sequence of tasks within the planned time frame and employing a minimum number of employees (Rodič, Baggia 2017). Groundwork tasks usually entail 
passenger check-in and baggage loading/unloading. According to Herbers (2005) staff scheduling typically comprises several stages: aggregation and analyses of workloads during demand planning; shift planning and appropriate shift duties; and finally rostering, which implies generating lines of duty for the workers.

The complexity of the airport crew scheduling problem arises from a large number of specifics. Flight frequency and the number of arrivals and departures vary during the day. Moreover, there are peaks in certain parts of the day. Consequently, the required number of workers differs depending on the day and part of the day. Demand changes within a flight. The number of passengers passing through an airport $2 \mathrm{~h}$ before departure is much lower than the number of passengers in the last half hour. Some destinations are more demanding and cause crowds, while those with less traffic constantly imply fewer passengers. Furthermore, qualifications of employees differ. Due to many tasks within ground services, the employees at the airport attend series of trainings. Qualification level represents a constraint in employee selection for different positions. In addition to work limitations, there are legal restrictions related to the number of working hours and working days during the week.

In summary, the solution to the airport ground crew scheduling problem should result in a schedule that is able to meet the anticipated demand, whereby employees should be assigned to activities in accordance with their qualification level and with respect to legal restrictions, which affects the assignment of employees by shifts and days. Certainly, labour costs minimization must be taken into account with maximum utilization of employees' capacity. In accordance with the specificities of different airports, many models and algorithms have been developed in order to provide support in solving this problem.

Brusco et al. (1995) directed their research towards effective scheduling of employees at counters and gates in airline stations of United Airlines (US). As a result, 2 modules are developed and implemented in order to enhance the tour scheduling process associated with United Airlines' Pegasys Manpower Planning System. Employee shifts are organized using column generation. A local search heuristic based on simulated annealing is used for the improvement of an initial feasible tour scheduling solution. In research by Chu (2007), the author proposes goal programming models for an integrated problem of crew duties assignment, in particular for the baggage services section staff at the Hong Kong International Airport. A goal programming based algorithm is used to determine the number of staff needed per hour and per day, and to generate daily schedules. Clausen (2010) described optimization problems from the perspective of airport ground handling. They consider specific optimization problems, which range from generalized approaches for workforce planning to highly detailed scheduling problems arising in the dynamic airport business. Soukour et al. (2013) presented a staff scheduling problem model for an airport security service. The problem is solved in 3 steps: (1) days off scheduling, (2) shift scheduling, and (3) staff assignment. For the staff assignment phase, the authors developed a memetic algorithm, which merged an evolutionary algorithm and local search techniques. An extensive amount of literature deals with models and methods for airport crew scheduling, for example Herbers (2005); Yen, Birge (2006); Santosa et al. (2010); Oketch (2013); Bazargan (2010); Kasirzadeh et al. (2017). However, a literature review indicates that more papers are focused on the problem of aircraft crew scheduling than on ground crew scheduling. More significantly, the majority of papers relevant to the topic considered in this paper discuss the problem of large international airports, while the problems of smaller airports are usually not taken into account.

\section{Problem and characteristics of crew scheduling on the "Constantine the Great" airport}

The airport "Constantine the Great" in the city of Niš is the third largest international airport in Serbia - IATA coding: INI (IATA 2019); ICAO coding: LYNI (ICAO 2019). Based on the number of passengers, it is the second largest civil airport in Serbia, after the "Nikola Tesla Airport" in Belgrade. In 2019, the number of passengers reached 422255 (NCGA 2019). Since 2015, the airport is focused on passenger flights of low-cost companies, thus contributing to the overall development of the city of Niš and Southern Serbia. In addition to passenger flights, the airport facilitates cargo flights as well. Air transport is carried out in cooperation with 2 low-cost airline companies (Ryanair and Wizz Air) and one traditional (Swiss Air). It is important to note the increased number of passengers and cargo between years $2014 \rightarrow 2015,2015 \rightarrow 2016$, $2016 \rightarrow 2017$ (Table 1).

The increased number of flights and passengers, which have gone through the airport daily since 2015, influenced the processes modification and the overall organization at the airport in order to support the current business volume. Today, organization comprises 3 basic sectors (top management, logistics and operational sector) and accompanying subsectors.

Table 1. Number of passengers and cargo statistics of "Constantine the Great" airport (NCGA 2019)

\begin{tabular}{|l|c|c|c|c|c|c|c|c|c|}
\hline Year & 2011 & 2012 & 2013 & 2014 & 2015 & 2016 & 2017 & 2018 & 2019 \\
\hline Number of passengers & 25130 & 27426 & 21700 & 1335 & 36258 & 124917 & 331582 & 351581 & 422255 \\
\hline Cargo [t] & 705 & 322 & 343 & 285 & 553 & 1967 & 2537 & 688 & 1180 \\
\hline
\end{tabular}


The largest sector of the airport is the operational sector with its subsectors: ground handling service, rescue and fire department, physical and technical security service, and technical maintenance service. One of the most important subsectors is the ground handling service. This subsector is related to passenger servicing and it has been directly influenced by the changes at the airport "Constantine the Great" in recent years. The ground handling service staff are responsible for the check-in procedure, access control, boarding, disembarkation, customs and baggage. These processes are grouped so that they operate without congestion and mixing of passengers. The groups include: flight preparation, passenger registration, access, security and passport control, gate, sorting of luggage, incoming and outgoing passengers.

\subsection{Characteristics of passenger servicing within ground handling service}

Passenger servicing within the ground handling service encompasses a total of 5 categories of employees. The categories are ordered according to difficulty level, the first being of the highest and the fifth of the lowest difficulty. Employees are trained for activities, starting from the easiest. Consequently, employees in higher categories are able to perform lower-category activities. The fifth category implies guiding the passengers from the plane landing spot to the exit gate and vice versa, which is part of the process of incoming and outgoing of passengers. It lasts an average of $30 \mathrm{~min}$, from landing to take-off. After completing training, the stewards move on to the fourth category, which refers to work on gates. The gate is open for $60 \mathrm{~min}$, during flight preparation until departure. The third category stewards perform passenger registration, including passport and reservation checks, boarding ticket printing, and hand baggage sorting. "Constantine the Great" has 4 counters assigned to such activities, while the number of engaged stewards depends on their availability and the number of passengers. The registration counter is open $2 \mathrm{~h}$ before the flight to $40 \mathrm{~min}$ before the flight, which is $80 \mathrm{~min}$ in total. The following, second category of stewards is in charge of access control. Access control involves checking the validity of passports, visas and other personal documents, as well as ensuring the compliance of data on the boarding pass with the data in the documents and the airport system. Access control counter is open during flight preparation, i.e. $120 \mathrm{~min}$. The first and the highest category stewards are supervisors on a flight. These stewards organize and monitor all subprocess related to incoming and outgoing passengers and solve adhoc problems. When the plain take-off supervisors send reports to landing airports and to the airline companies, and the flight is closed.

\subsection{Ground crew scheduling problem characteristics}

Crew scheduling problem is one of the core problems at "Constantine the Great". Airport activities depend on travel intensity, flight structure, seasonality, etc. Working hours have to be adjusted to daily needs, with no regular shifts. An additional constraint is to match the activities and categories of stewards. The scheduling problem requires inactivity minimization. There is free time between flights, in which the stewards are paid but perform no tasks.

Employees scheduling depends on a flight plan. A lack of activities outside the boarding and flight preparation time implies that employees should not be scheduled within that period. Ground handling services are realized about $2 \mathrm{~h}$ before flights. During those $2 \mathrm{~h}$, the number of passengers varies. The required number of employees should be defined for each workplace and each time interval. Shorter time intervals generate a more precise schedule. Furthermore, departures at the airport can overlap, which causes the doubling or even tripling of the required number of employees.

One of the main goals of crew scheduling is demand satisfaction. This goal can be defined as a constraint of the model. Another goal is to minimize passenger waiting time. However, this goal is conflicted with the goal of cost minimization, which requires a decrease in the number employees and engaged working hours. Therefore, minimization of hours without activities spent at the airport can be defined as a goal. In order to reconcile all of these goals, a minimum number of stewards should be defined and the objective function can be set as minimum divergence between the scheduled and minimum number of stewards. The complexity of the scheduling problem arises from conflicted objective functions and a wide range of constraints. Many authors have tackled this problem. Table 2 presents a comparison of the characteristics of the scheduling problem at the airport "Constantine the Great" and the characteristics modelled in some of the papers mentioned in Section 1.

All analysed models have some similarity with the characteristics of the scheduling problem at the airport "Constantine the Great". However, the following specificities of this airport scheduling problem prevent their implementation:

"» objective function of the model that describes the scheduling problem at the "Constantine the Great" airport has to include minimization of working hours with no activities;

") scheduling has to consider activities divided by categories;

"» time constraints.

\section{Mathematical formulation}

We consider a discrete time system control process corresponding to the ground crew scheduling problem at "Constantine the Great" airport. Based on input data on the flight beginning, the model enables the calculation of number of activities for a given time period. Working hours and activities are defined in accordance with discrete time units of time horizon. Working day is discretized in intervals of $5 \mathrm{~min}$ in order to encompass all 
Table 2. Comparison of scheduling problem characteristics

\begin{tabular}{|c|c|c|c|c|c|c|c|c|c|}
\hline $\begin{array}{c}\text { Problems } \\
\text { described in }\end{array}$ & \multicolumn{9}{|c|}{ Characteristics } \\
\hline $\begin{array}{l}\text { "Constantine } \\
\text { the Great" } \\
\text { airport }\end{array}$ & $\begin{array}{l}\text { categories } \\
\text { of activities }\end{array}$ & $\begin{array}{l}\text { fixed } \\
\text { duration } \\
\text { of } \\
\text { activities }\end{array}$ & \begin{tabular}{|l} 
shifts \\
are not \\
strictly \\
defined
\end{tabular} & $\begin{array}{l}\text { working } \\
\text { hours per } \\
\text { week are } \\
\text { constrained }\end{array}$ & \begin{tabular}{|l} 
defined \\
minimum of \\
non-working \\
hours
\end{tabular} & $\begin{array}{l}\text { minimum } \\
2 \text { free days } \\
\text { per week }\end{array}$ & \begin{tabular}{|l|} 
maximum \\
of \\
overtime \\
hours \\
exists
\end{tabular} & $\begin{array}{l}\text { the path } \\
\text { between } \\
\text { work places } \\
\text { is not } \\
\text { significant }\end{array}$ & \begin{tabular}{|l} 
objective \\
function \\
includes \\
minimization \\
of working \\
hours without \\
activities
\end{tabular} \\
\hline Chu (2007) & $\begin{array}{l}\text { activities } \\
\text { are not } \\
\text { categorized }\end{array}$ & $\begin{array}{l}\text { fixed } \\
\text { duration } \\
\text { of } \\
\text { activities }\end{array}$ & $\begin{array}{l}\text { shifts } \\
\text { are not } \\
\text { strictly } \\
\text { defined }\end{array}$ & $\begin{array}{l}\text { working } \\
\text { hours } \\
\text { per week } \\
\text { are not } \\
\text { constrained }\end{array}$ & $\begin{array}{l}\text { minimum of } \\
\text { non-working } \\
\text { hours is not } \\
\text { defined }\end{array}$ & $\begin{array}{l}2 \text { consecu- } \\
\text { tive free } \\
\text { days per } \\
\text { week }\end{array}$ & \begin{tabular}{|l|} 
overtime \\
hours \\
constraint \\
does not \\
exist
\end{tabular} & $\begin{array}{l}\text { the path } \\
\text { between } \\
\text { work places } \\
\text { is not } \\
\text { significant }\end{array}$ & $\begin{array}{l}\text { objective } \\
\text { function } \\
\text { includes } \\
\text { minimization } \\
\text { of labour costs }\end{array}$ \\
\hline $\begin{array}{l}\text { Soukour } \\
\text { et al. }(2013)\end{array}$ & $\begin{array}{l}\text { categories } \\
\text { of activities }\end{array}$ & $\begin{array}{l}\text { duration } \\
\text { of } \\
\text { activities } \\
\text { is not } \\
\text { fixed }\end{array}$ & $\begin{array}{l}\text { defined } \\
\text { shifts }\end{array}$ & $\begin{array}{l}\text { working } \\
\text { hours per } \\
\text { week are } \\
\text { constrained }\end{array}$ & $\begin{array}{l}\text { defined } \\
\text { minimum of } \\
\text { non-working } \\
\text { hours }\end{array}$ & \begin{tabular}{|l|} 
adapted to \\
different \\
time \\
constraints
\end{tabular} & \begin{tabular}{|l|} 
adapted to \\
different \\
time \\
constraints
\end{tabular} & $\begin{array}{l}\text { the path } \\
\text { between } \\
\text { work places } \\
\text { is not } \\
\text { significant }\end{array}$ & $\begin{array}{l}\text { objective } \\
\text { function } \\
\text { includes } \\
\text { minimization } \\
\text { of labour costs }\end{array}$ \\
\hline $\begin{array}{l}\text { Brusco et al. } \\
(1995)\end{array}$ & $\begin{array}{l}\text { activities } \\
\text { are not } \\
\text { categorized }\end{array}$ & $\begin{array}{l}\text { activities } \\
\text { are not } \\
\text { divided }\end{array}$ & $\begin{array}{l}\text { shifts } \\
\text { are not } \\
\text { strictly } \\
\text { defined }\end{array}$ & $\begin{array}{l}\text { working } \\
\text { hours per } \\
\text { week are } \\
\text { constrained }\end{array}$ & $\begin{array}{l}\text { defined } \\
\text { minimum of } \\
\text { non-working } \\
\text { hours }\end{array}$ & $\begin{array}{l}\text { minimum } \\
2 \text { free days } \\
\text { per week }\end{array}$ & \begin{tabular}{|l|} 
overtime \\
hours \\
constraint \\
does not \\
exist
\end{tabular} & $\begin{array}{l}\text { the path } \\
\text { between } \\
\text { work places } \\
\text { is not } \\
\text { significant }\end{array}$ & $\begin{array}{l}\text { objective } \\
\text { function } \\
\text { includes } \\
\text { minimization } \\
\text { of labour costs }\end{array}$ \\
\hline $\begin{array}{l}\text { Clausen } \\
(2010)\end{array}$ & $\begin{array}{l}\text { activities } \\
\text { are not } \\
\text { categorized }\end{array}$ & $\begin{array}{l}\text { activities } \\
\text { are not } \\
\text { divided }\end{array}$ & $\begin{array}{l}\text { shifts } \\
\text { are not } \\
\text { strictly } \\
\text { defined }\end{array}$ & $\begin{array}{l}\text { working } \\
\text { hours per } \\
\text { week are } \\
\text { constrained }\end{array}$ & $\begin{array}{l}\text { defined } \\
\text { minimum of } \\
\text { non-working } \\
\text { hours }\end{array}$ & \begin{tabular}{|l} 
adapted to \\
different \\
time \\
constraints
\end{tabular} & \begin{tabular}{|l|} 
adapted to \\
different \\
time \\
constraints
\end{tabular} & $\begin{array}{l}\text { the path } \\
\text { between } \\
\text { work } \\
\text { places is } \\
\text { significant }\end{array}$ & $\begin{array}{l}\text { objective } \\
\text { function } \\
\text { includes } \\
\text { minimization } \\
\text { of } \\
\text { transportation } \\
\text { costs }\end{array}$ \\
\hline
\end{tabular}

possible flight beginnings. Finite time horizon $T$ consists of 144 time periods in accordance with airport working hours (from 7:00 to 19:00). Every flight involves 5 basic activities. The categories and the number of stewards and the time of execution are known for each activity within the flight realization. Activities are unique. If an activity requires more than one steward, it has to be divided into more activities with the same characteristics. All identified activities are denoted with a unique code and make a set of activities $N$. Parameter $k_{j}$ defines category of activity $j$, which conditions the assignment of stewards with appropriate qualifications. This parameter takes values from 1 to 5. Stewards' qualifications $k v_{i}$ correspond to categories of activities and take values from 1 to 5 . Acceptable differences between $k v_{i}$ and $k_{j}$ are 0 and 1, i.e. a steward cannot be assigned to an activity more than one level lower than his or her qualification.

Legal regulations impose minimum and maximum working time, as well as minimum duration of breaks within the day. Parameter NKRV refers to the shortest work time and $N D R V$ refers to the longest. NMP stands for minimum duration of break.

The ground crew scheduling problem described in this paper considers several constraints. Availability constraint - Equation (1) - ensures that a steward can be assigned to one activity the most per one time unit:

$$
\sum_{j \in N} x_{i j} \cdot t r_{t j} \leq 1
$$

$i \in S ; t=1, \ldots, T$.

Activity coverage - Equation (2) - secures that each activity will be assigned a steward:

$$
\sum_{i \in S} x_{i j} \cdot t r_{t j}=1 \text {, }
$$

$j \in N ; t=1, \ldots, T$.

Maximum working time constraint - Equation (3) forbids defining shifts longer than the predefined maximum:

$$
\sum_{t=1}^{T} z a_{i t} \leq N D R V,
$$

$i \in S$.

Minimum working time constraint - Equation (4) forbids defining shifts shorter than the predefined minimum:

$$
\sum_{t=1}^{T} z a_{i t} \geq N K R V,
$$

$i \in S$. 
The minimum duration of a break is defined by constraint - Equation (5):

$$
\begin{aligned}
& \sum_{t=1}^{T} z a_{i t}-\sum_{j \in N} \sum_{t=1}^{T} x_{i j} \cdot t r_{t j} \geq N M P, \\
& i \in S .
\end{aligned}
$$

Constraints related to upper (Equation (6)) and lower (Equation (7)) limits of categories imply the assignment of activities to stewards with the appropriate qualifications or a higher qualification level. Additionally, an activity assigned to a steward cannot be more than one category lower than the steward's qualification.

$$
\begin{aligned}
& k v_{i} \cdot x_{i j}-k_{j} \cdot x_{i j} \leq 1, \\
& i \in S ; j \in N . \\
& k v_{i} \cdot x_{i j}-k_{j} \cdot x_{i j} \geq 0, \\
& i \in S ; j \in N .
\end{aligned}
$$

The ground crew scheduling problem at the "Constantine the Great" airport does not correspond to a common objective function of cost minimization of engaged stewards, because of fixed fees. The scheduling problem is characterized by breaks between flights during which the stewards have no activities. Consequently, the aim of this model is the minimization of working hours without activities. The objective function - Equation (8) - is defined as the minimum deviation of the duration of shifts of all stewards and the duration of all activities.

$$
\min J=\sum_{i=1}^{S} \sum_{t=1}^{T} z a_{i t}-\sum_{j=1}^{N} t p_{j} .
$$

All model variables are considered in discrete time units and all relations of the model are linear.

\section{Spreadsheet implementation}

In order to test it, the developed model is implemented as a simulation model in a spreadsheet environment $\mathrm{Mi}$ crosoft Excel. The spreadsheet simulation model improves and facilitates the understanding of the scheduling process through the dynamic, flexible, easy to use and affordable tool. The model consists of 3 modules: (1) input, (2) calculation and (3) output.

Direct input data include the beginning of each flight during the day, as well as the start, the duration, the number of required stewards and category for each activity within the flight. Start time of a flight expressed in a real time unit has to be converted to a discrete time unit number. The cells in yellow are intended for user input (Figure 1). The start and end of all activities is defined based on a time unit reflecting the flight beginning. The number of flights defines the total number of activities. Each activity has to be coded. The code consists of 3 elements. The first element represents a two-digit serial number of the activity, the second is a one-digit category of the activity, the third part is information related to the number of required stewards. An example of activities arrays, includ- ing code, start $a_{j}$, end $b_{j}$, duration $t p_{j}$ and category $k_{j}$, are presented in Figure 1.

Parameters $p_{t j}, z_{t j}$ and $t r_{t j}(t=1, \ldots, T ; j=1, \ldots, N)$ are calculated in accordance with the start and end time. Their values are represented through the matrix defined by rows, which indicate time units and columns, which indicate activities. Binary parameter $p_{t j}$ takes value 1 in the time unit of beginning, otherwise it is zero. The same logic applies to parameter $z_{t j}$. Binary parameter $t r_{t j}$ depends on $p_{t j}$ and $z_{t j}$. It is 1 if activity $j$ is in progress in time unit $t$, i.e. for periods greater than or equal to the start period and less than the end time.

Input data related to stewards include their qualifications $k v_{i}$. A steward's qualification defines her or his training level and competence for different activities. The qualification level of stewards corresponds to categories of activities.

Calculation module implements a mathematical model described in the previous section. In order to facilitate simulation, the model includes one main control variable $x_{i j}$ that should be entered by end-users. An example of the control variable values is presented in Figure 2, with matrix defined by rows $i$ and columns $j$.

Auxiliary variables are calculated based on $x_{i j}$ values. Variable $s_{i}$ is related to the start time of a shift for a steward, i.e. the earliest beginning of the first activity $(i=1$, $\ldots, S)$. Auxiliary variable $p s_{i}$ is used for the calculation of the start of all activities for a steward, while $s_{i}$ takes the minimum value for every steward. Defining the end of a

\begin{tabular}{|c|c|c|c|c|c|c|}
\hline 4 & A & c & D & $E$ & $\mathrm{~F}$ & G \\
\hline 1 & FLIGHT NUMBER & 01 & 02 & & & \\
\hline 2 & $\begin{array}{l}\text { FLIGHT BEGINNING } \\
\text { (real time) }\end{array}$ & $11: 30$ & $13: 35$ & & & \\
\hline 3 & $\begin{array}{c}\text { FLIGHT BEGINNING } \\
\text { (time period) }\end{array}$ & 55 & 80 & & & \\
\hline 4 & ACTIVITIES & Supervision & ccess contr & egistration & Gate & Guiding \\
\hline 5 & START & 0 & 0 & 0 & 12 & 18 \\
\hline 6 & END & 24 & 24 & 16 & 24 & 24 \\
\hline 7 & NO OF STEWARDESSES & 1 & 1 & 2 & 1 & 4 \\
\hline 8 & CATEGORY & 1 & 2 & 3 & 4 & 5 \\
\hline \multicolumn{2}{|l|}{9} & & & & & \\
\hline 10 & & Activities & & & & \\
\hline \multirow[t]{2}{*}{11} & & Parameters & $k_{j}$ & $a_{j}$ & $b_{j}$ & $\mathrm{tp}_{\mathrm{i}}$ \\
\hline & & Code & Category & Start & End & Duration \\
\hline 13 & & 0111 & 1 & 55 & 79 & 24 \\
\hline 14 & & 0121 & 2 & 55 & 79 & 24 \\
\hline 15 & & 0131 & 3 & 55 & 71 & 16 \\
\hline 16 & & 0132 & 3 & 55 & 71 & 16 \\
\hline 17 & & 0141 & 4 & 67 & 79 & 12 \\
\hline 18 & & 0151 & 5 & 73 & 79 & 6 \\
\hline 19 & & 0152 & 5 & 73 & 79 & 6 \\
\hline 20 & & 0153 & 5 & 73 & 79 & 6 \\
\hline 21 & & 0154 & 5 & 73 & 79 & 6 \\
\hline 22 & & 0211 & 1 & 80 & 104 & 24 \\
\hline 23 & & 0221 & 2 & 80 & 104 & 24 \\
\hline 24 & & 0231 & 3 & 80 & 96 & 16 \\
\hline 25 & & 0232 & 3 & 80 & 96 & 16 \\
\hline 26 & & 0241 & 4 & 92 & 104 & 12 \\
\hline 27 & & 0251 & 5 & 98 & 104 & 6 \\
\hline 28 & & 0252 & 5 & 98 & 104 & 6 \\
\hline 29 & & 0253 & 5 & 98 & 104 & 6 \\
\hline 30 & & 0254 & 5 & 98 & 104 & 6 \\
\hline
\end{tabular}
shift implies a similar logic. Auxiliary variable $p z_{i}$ refers to time units when all activities of a steward end, i.e. the end of a shift. Additional variable $e_{i}$ is the maximum of $p z_{i}$. Based on the shift beginning and ending time unit, variable $z a_{i t}$ indicates whether the steward is at the airport during the specific time period.

Figure 1. Example of activities arrays including code, category, start, end and duration 


\begin{tabular}{|c|c|c|c|c|c|c|c|c|c|c|c|c|c|c|c|c|c|c|c|}
\hline 4 & A & B & C & D & E & $\mathrm{F}$ & G & H & 1 & J & K & $\mathrm{L}$ & $M$ & $\mathrm{~N}$ & 0 & $P$ & Q & $R$ & $S$ \\
\hline 6 & $\mathrm{x}_{i j}$ & 0111 & 0121 & 0131 & 0132 & 0141 & 0151 & 0152 & 0153 & 0154 & 0211 & 0221 & 0231 & 0232 & 0241 & 0251 & 0252 & 0253 & 0254 \\
\hline 7 & S1 & 1 & 0 & 0 & 0 & 0 & 0 & 0 & 0 & 0 & 1 & 0 & 0 & 0 & 0 & 0 & 0 & 0 & 0 \\
\hline 8 & S2 & 0 & 1 & 0 & 0 & 0 & 0 & 0 & 0 & 0 & 0 & 1 & 0 & 0 & 0 & 0 & 0 & 0 & 0 \\
\hline 9 & S3 & 0 & 0 & 1 & 0 & 0 & 0 & 0 & 0 & 0 & 0 & 0 & 1 & 0 & 0 & 0 & 0 & 0 & 0 \\
\hline 10 & S4 & 0 & 0 & 0 & 1 & 0 & 0 & 0 & 0 & 0 & 0 & 0 & 0 & 1 & 0 & 0 & 0 & 0 & 0 \\
\hline 11 & S5 & 0 & 0 & 0 & 0 & 1 & 0 & 0 & 0 & 0 & 0 & 0 & 0 & 0 & 1 & 0 & 0 & 0 & 0 \\
\hline 12 & S6 & 0 & 0 & 0 & 0 & 0 & 1 & 0 & 0 & 0 & 0 & 0 & 0 & 0 & 0 & 1 & 0 & 0 & 0 \\
\hline 13 & S7 & 0 & 0 & 0 & 0 & 0 & 0 & 1 & 0 & 0 & 0 & 0 & 0 & 0 & 0 & 0 & 1 & 0 & 0 \\
\hline 14 & S8 & 0 & 0 & 0 & 0 & 0 & 0 & 0 & 1 & 0 & 0 & 0 & 0 & 0 & 0 & 0 & 0 & 1 & 0 \\
\hline 15 & S9 & 0 & 0 & 0 & 0 & 0 & 0 & 0 & 0 & 1 & 0 & 0 & 0 & 0 & 0 & 0 & 0 & 0 & 1 \\
\hline
\end{tabular}

Figure 2. Example of control variable $x_{i j}$ values, $1-$ steward $i$ realizes activity $j ; 0$ - otherwise

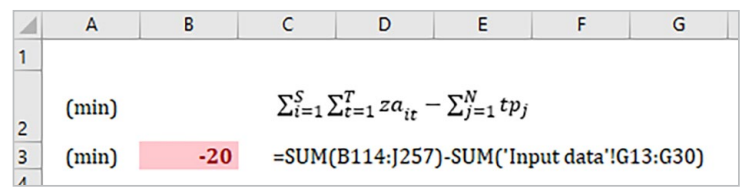

Figure 3. Spreadsheet implementation of the objective function

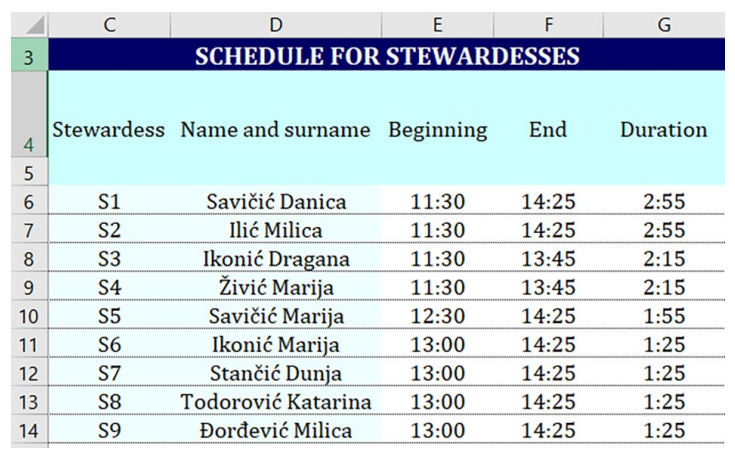

Figure 4. Example of stewards' schedule, resulting from the model

The objective function (Equation (8)) is defined as minimum deviation of the duration of shifts of all stewards and the duration of all activities. Consequently, this deviation cannot be less than zero. Value less than zero indicates that tasks are not covered by stewards. Example illustrated in Figure 3 represents a case where stewards are not assigned for 20 time units of activities. Conditional formatting technique is used for spreadsheet implementation of the objective function.

The spreadsheet simulation model enables end-users to vary values of control variable $x_{i j}$. The previously described constraints are implemented in such a manner that guide the user to feasible solutions. Availability constraint - Equation (1) - shows that some activities assigned to stewards overlap. The number of overlapping time units cause a negative value of the objective function. Activity coverage constraint - Equation (2) - ensures that each activity has one steward assigned. Constraints - Equations (3) and (4) - ensure that the working time of stewards is not longer than 10 or shorter than $4 \mathrm{~h}$. Constraint - Equation (5) - refers to a break of minimum 30 min. Constraints - Equations (6) and (7) - define upper and lower limits of categories of activities and assigned stewards. If all deviations result in zero value, it means that categories of activities correspond to qualifications of assigned stewards.
The described simulation model enables comparison of different scenarios by assigning activities to stewards, whereby conditionally formatted constraints signal an inadmissible solution. Output module represents a report that reflects a schedule for stewards, considering the shift start and end, as well as shift duration (Figure 4).

In order to facilitate data preparation, constraint implementation and reporting, the authors developed UDFs in Visual Basic for Application. UDFs are used for the transformation of real-time data to time units, the definition of activities in accordance with the selected flight, the minimization of breaks, and the creation of reports.

\section{Sensitivity analysis and numerical results}

In order to evaluate the developed control model for ground crew scheduling and analyse its efficiency, preliminary test was performed on 5 randomly generated instances for one to 5 flights.

The following assumptions were considered during the model evaluation:

"») duration, order and number of activities per flight is predefined and cannot be changed (Table 3 );

"») activities within the flight start at defined time units, which are unchangeable and interconnected (Figure 5);

"») each activity has to be assigned to a single steward, i.e. one activity cannot be realized by more than one steward;

"» the total number of qualified stewards has to correspond to the defined categories of activities. As mentioned previously, stewards' qualifications $k v_{i}$ correspond to the categories of activities and take values from 1 to 5 . There are 9 available stewards for the defined number of 5 activities (Table 4);

"») overlapping of flights is not allowed. If this happens, it is necessary to engage a completely new shift of 9 stewards. Scheduling of 9 stewards in a parallel shift for an overlapped flight is the same as in the described problem;

"'» maximum working time is defined as 8 regular working hours and $2 \mathrm{~h}$ overtime, i.e. $40 \mathrm{~h}$ per week and 2 days off. Minimum duration of a shift is $4 \mathrm{~h}$;

"») total break duration has to be at least half-hour for a regular shift.

Based on the duration of activities per flight presented in Table 3 and Figure 5, it can be concluded that the 
difference between the start of the 2 consecutive flights has to be at least $2 \mathrm{~h}$ and $5 \mathrm{~min}(25$ time units $\times 5 \mathrm{~min}$ ). Otherwise, an overlap of the ending of activities within the first flight and the beginning of activities of the same category within the second one will cause an infeasible solution to the scheduling problem (Figure 6).

Taking into consideration all the assumptions previously described and ranges of input data presented in Table 3, a control model for the ground crew scheduling problem is evaluated for the instances of 2, 3, 4 and 5 flights. Control variables values are defined in accordance with categories of stewards and activities (Table 3 and Table 4) and constraints - Equations (6) and (7).

Analysis results for the instance of 1 flight are not shown in detail because the total duration of activities within the flight is far shorter than the total available working hours of stewards. Therefore, scheduling is easy, but unfeasible from the aspect of the minimum working time constraint.

Input data for instance of 2 flights are already presented in Figure 1. The results in Table 5 indicate that nonworking hours of engaged stewards are $68 \%$ of maximum working hours. Nevertheless, the obtained solution is also unfeasible, for the same reason as for the first instance. Non-working hours are considered as the difference between maximum working time and shift duration. Shift

Table 3. The ranges of input data

\begin{tabular}{|l|c|c|c|c|c|}
\hline \multicolumn{1}{|c|}{ Flight number } & 01 & 02 & 03 & 04 & 05 \\
\hline $\begin{array}{l}\text { Flight beginning } \\
\text { (real time) }\end{array}$ & $11: 30$ & $13: 35$ & $15: 40$ & $17: 45$ & $19: 50$ \\
\hline $\begin{array}{l}\text { Flight beginning } \\
\text { (time period) }\end{array}$ & 55 & 80 & 105 & 130 & 155 \\
\hline Activity & $\begin{array}{l}\text { super- } \\
\text { vision }\end{array}$ & $\begin{array}{c}\text { access } \\
\text { control }\end{array}$ & $\begin{array}{c}\text { regis- } \\
\text { tration }\end{array}$ & gate & $\begin{array}{c}\text { guid- } \\
\text { ing }\end{array}$ \\
\hline $\begin{array}{l}\text { Start } \\
\text { (time period) }\end{array}$ & 0 & 0 & 0 & 12 & 18 \\
\hline $\begin{array}{l}\text { End } \\
\text { (time period) }\end{array}$ & 24 & 24 & 16 & 24 & 24 \\
\hline No of stewards & 1 & 1 & 2 & 1 & 4 \\
\hline Category & 1 & 2 & 3 & 4 & 5 \\
\hline
\end{tabular}

Table 4. Stewards' qualification level (category)

\begin{tabular}{|c|c|}
\hline Steward & Qualification $k v_{i}$ \\
\hline S1 & 1 \\
\hline S2 & 2 \\
\hline S3 & 3 \\
\hline S4 & 3 \\
\hline S5 & 4 \\
\hline S6 & 5 \\
\hline S7 & 5 \\
\hline S8 & 5 \\
\hline S9 & 5 \\
\hline
\end{tabular}

duration represents the time between the start of the first activity and the end of the last one for a steward. Shift duration, presented in the tables with numerical results, includes periods with no assigned activities for stewards within a shift.

The model is tested in the same manner for other instances, for up to 5 flights. Flights beginnings are set up with a predefined difference of $2 \mathrm{~h}$ and $5 \mathrm{~min}$. Numerical results are presented in Tables 6-8.

Experiments carried out for instances of 3 and 4 flights generate feasible solutions. Additionally, numerical results (Table 6 and Table 7) show a reduction in the percentage of non-working hours with the number of flights increment. The break duration constraint is not considered in these experiments, given that shift duration does not reach 8 working hours in almost all cases.

In the case of 5 flights (Table 8), the solution is unfeasible because shift duration for stewards S1 and S2 exceeds maximum working time for $20 \mathrm{~min}$. Additionally, for stewards S3 and S4, the minimum break duration constraint is violated.

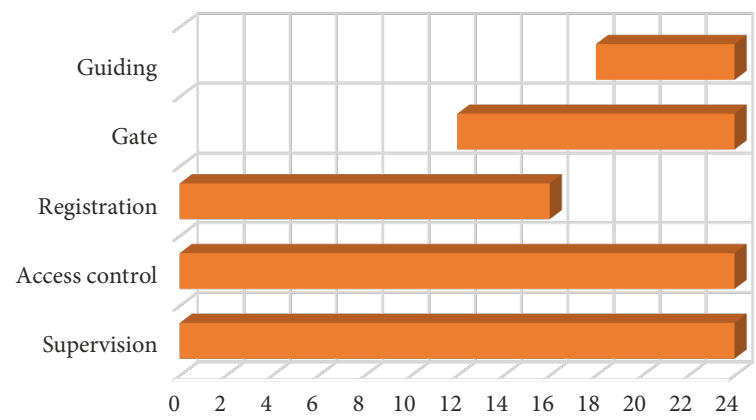

Figure 5. Activities within the flight (start and duration)

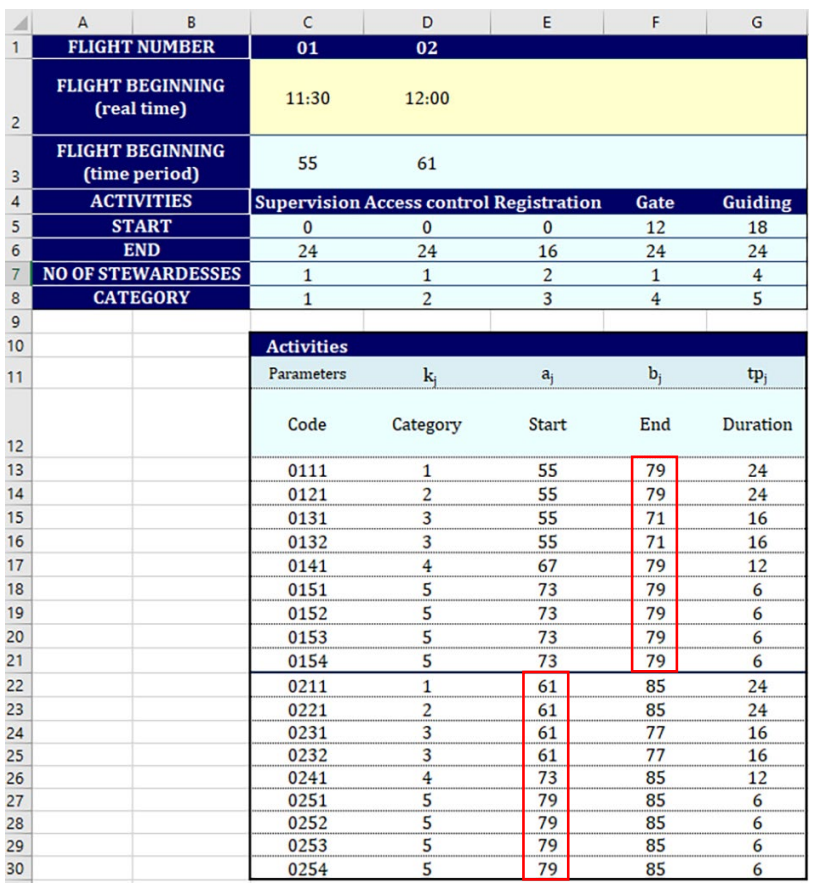

Figure 6. Example of overlapped activities for 2 flights 
Table 9 presents a summary of results for all analysed instances. This comparative analysis includes total unused hours during a shift, which is actually the objective function defined by the model. The unused hours during a shift refer to periods with no assigned activities for stewards within a shift. The results indicate that, although it generates the lowest percentage of total unused hours during a shift, the 1 flight instance implies the longest non-working time per shift. 1 flight instance results can be argued by total shift duration of only 9:40 h for all stewards. As previously mentioned, non-working hours are considered as the difference between maximum work- ing time and shift duration. Shift duration represents the time between the beginning of the first activity and the end of the last one for a steward, including periods without assigned activities. 1 flight schedule is unfeasible because of the minimum working time constraint. Instance of 4 flights generates the best feasible solution, with 33\% of total unused hours during the shift and non-working hours of 24:05 h. Despite the infeasible solution in the instance of 5 flights because the constraint of maximum working time and minimum duration of break is violated, the total number of unused hours during a shift and nonworking hours is the lowest.

Table 5. Numerical results for instance of 2 flights

\begin{tabular}{|c|c|c|c|c|c|c|}
\hline Steward & $\begin{array}{c}\text { Beginning of } \\
\text { the shift }\end{array}$ & $\begin{array}{c}\text { End of the } \\
\text { shift }\end{array}$ & $\begin{array}{c}\text { Shift duration } \\
{[\mathrm{h}]}\end{array}$ & $\begin{array}{c}\text { Maximum working time } \\
{[\mathrm{h}]}\end{array}$ & $\begin{array}{c}\text { Non-working hours } \\
{[\mathrm{h}]}\end{array}$ & $\begin{array}{c}\text { Non-working hours } \\
{[\%]}\end{array}$ \\
\hline S1 & $11: 30$ & $15: 35$ & $04: 05$ & $10: 00$ & $05: 55$ & 59 \\
\hline S2 & $11: 30$ & $15: 35$ & $04: 05$ & $10: 00$ & $05: 55$ & 59 \\
\hline S3 & $11: 30$ & $14: 55$ & $03: 25$ & $10: 00$ & $06: 35$ & 66 \\
\hline S4 & $11: 30$ & $14: 55$ & $03: 25$ & $10: 00$ & $06: 35$ & 66 \\
\hline S5 & $12: 30$ & $15: 35$ & $03: 05$ & $10: 00$ & $06: 55$ & 69 \\
\hline S6 & $13: 00$ & $15: 35$ & $02: 35$ & $10: 00$ & $07: 25$ & 74 \\
\hline S7 & $13: 00$ & $15: 35$ & $02: 35$ & $10: 00$ & $07: 25$ & 74 \\
\hline S8 & $13: 00$ & $15: 35$ & $02: 35$ & $10: 00$ & $07: 25$ & \\
\hline S9 & $13: 00$ & $15: 35$ & $02: 35$ & $10: 00$ & $07: 25$ & 74 \\
\hline
\end{tabular}

Table 6. Numerical results for instance of 3 flights

\begin{tabular}{|c|c|c|c|c|c|c|}
\hline Steward & $\begin{array}{c}\text { Beginning of } \\
\text { the shift }\end{array}$ & $\begin{array}{c}\text { End of the } \\
\text { shift }\end{array}$ & $\begin{array}{c}\text { Shift duration } \\
{[\mathrm{h}]}\end{array}$ & $\begin{array}{c}\text { Maximum working time } \\
{[\mathrm{h}]}\end{array}$ & $\begin{array}{c}\text { Non-working hours } \\
{[\mathrm{h}]}\end{array}$ & $\begin{array}{c}\text { Non-working hours } \\
{[\%]}\end{array}$ \\
\hline S1 & $11: 30$ & $17: 40$ & $06: 10$ & $10: 00$ & $03: 50$ & 38 \\
\hline S2 & $11: 30$ & $17: 40$ & $06: 10$ & $10: 00$ & $03: 50$ & 38 \\
\hline S3 & $11: 30$ & $17: 00$ & $05: 30$ & $10: 00$ & $04: 30$ & 45 \\
\hline S4 & $11: 30$ & $17: 00$ & $05: 30$ & $10: 00$ & $04: 30$ & 45 \\
\hline S5 & $12: 30$ & $17: 40$ & $05: 10$ & $10: 00$ & $04: 50$ & 48 \\
\hline S6 & $13: 00$ & $17: 40$ & $04: 40$ & $10: 00$ & $05: 20$ & 53 \\
\hline S7 & $13: 00$ & $17: 40$ & $04: 40$ & $10: 00$ & $05: 20$ & 53 \\
\hline S8 & $13: 00$ & $17: 40$ & $04: 40$ & $10: 00$ & $05: 20$ & 53 \\
\hline S9 & $13: 00$ & $17: 40$ & $04: 40$ & $10: 00$ & $05: 20$ & 52 \\
\hline
\end{tabular}

Table 7. Numerical results for instance of 4 flights

\begin{tabular}{|c|c|c|c|c|c|c|}
\hline Steward & $\begin{array}{c}\text { Beginning of } \\
\text { the shift }\end{array}$ & $\begin{array}{c}\text { End of the } \\
\text { shift }\end{array}$ & $\begin{array}{c}\text { Shift duration } \\
{[\mathrm{h}]}\end{array}$ & $\begin{array}{c}\text { Maximum working time } \\
{[\mathrm{h}]}\end{array}$ & $\begin{array}{c}\text { Non-working hours } \\
{[\mathrm{h}]}\end{array}$ & $\begin{array}{c}\text { Non-working hours } \\
{[\%]}\end{array}$ \\
\hline S1 & $11: 30$ & $19: 45$ & $08: 15$ & $10: 00$ & $01: 45$ & 18 \\
\hline S2 & $11: 30$ & $19: 45$ & $08: 15$ & $10: 00$ & $01: 45$ & 18 \\
\hline S3 & $11: 30$ & $19: 05$ & $07: 35$ & $10: 00$ & $02: 25$ & 24 \\
\hline S4 & $11: 30$ & $19: 05$ & $07: 35$ & $10: 00$ & $02: 25$ & 24 \\
\hline S5 & $12: 30$ & $19: 45$ & $07: 15$ & $10: 00$ & $02: 45$ & 28 \\
\hline S6 & $13: 00$ & $19: 45$ & $06: 45$ & $10: 00$ & $03: 15$ & 33 \\
\hline S7 & $13: 00$ & $19: 45$ & $06: 45$ & $10: 00$ & $03: 15$ & 33 \\
\hline S8 & $13: 00$ & $19: 45$ & $06: 45$ & $10: 00$ & $03: 15$ & 33 \\
\hline S9 & $13: 00$ & $19: 45$ & $06: 45$ & $10: 00$ & $03: 15$ & \\
\hline
\end{tabular}


Table 8. Numerical results for instance of 5 flights

\begin{tabular}{|c|c|c|c|c|c|c|}
\hline Steward & $\begin{array}{c}\text { Beginning } \\
\text { of the shift }\end{array}$ & $\begin{array}{c}\text { End of the } \\
\text { shift }\end{array}$ & $\begin{array}{c}\text { Shift duration } \\
{[\mathrm{h}]}\end{array}$ & $\begin{array}{c}\text { Maximum working time } \\
{[\mathrm{h}]}\end{array}$ & $\begin{array}{c}\text { Non-working hours } \\
{[\mathrm{h}]}\end{array}$ & $\begin{array}{c}\text { Non-working hours } \\
{[\%]}\end{array}$ \\
\hline S1 & $11: 30$ & $21: 50$ & $10: 20$ & $10: 00$ & $00: 00$ & 0 \\
\hline S2 & $11: 30$ & $21: 50$ & $10: 20$ & $10: 00$ & $00: 00$ & 0 \\
\hline S3 & $11: 30$ & $21: 10$ & $09: 40$ & $10: 00$ & $00: 20$ & 3 \\
\hline S4 & $11: 30$ & $21: 10$ & $09: 40$ & $10: 00$ & $00: 20$ & 3 \\
\hline S5 & $12: 30$ & $21: 50$ & $09: 20$ & $10: 00$ & $00: 40$ & 7 \\
\hline S6 & $13: 00$ & $21: 50$ & $08: 50$ & $10: 00$ & $01: 10$ & 12 \\
\hline S7 & $13: 00$ & $21: 50$ & $08: 50$ & $10: 00$ & $01: 10$ & 12 \\
\hline S8 & $13: 00$ & $21: 50$ & $08: 50$ & $10: 00$ & $01: 10$ & 12 \\
\hline S9 & $13: 00$ & $21: 50$ & $08: 50$ & $10: 00$ & $01: 10$ & 12 \\
\hline
\end{tabular}

Table 9. Summary results for instances of 1 to 5 flights

\begin{tabular}{|c|c|c|c|c|c|c|}
\hline $\begin{array}{c}\text { Number of } \\
\text { flights }\end{array}$ & $\begin{array}{c}\text { Number of } \\
\text { stewards }\end{array}$ & $\begin{array}{c}\text { Total shift duration } \\
\text { for all stewards [h] }\end{array}$ & $\begin{array}{c}\text { Non-working } \\
\text { hours for all } \\
\text { stewards [h] }\end{array}$ & $\begin{array}{c}\text { Non-working } \\
\text { hours for all } \\
\text { stewards [\%] }\end{array}$ & $\begin{array}{c}\text { Total unused hours } \\
\text { during the shift [h] }\end{array}$ & $\begin{array}{c}\text { Total unused hours } \\
\text { during the shift [\%] }\end{array}$ \\
\hline 1 & 9 & $09: 40$ & $64: 20$ & 71 & $00: 45$ & 8 \\
\hline 2 & 9 & $28: 25$ & $61: 35$ & 68 & $09: 50$ & 35 \\
\hline 3 & 9 & $47: 10$ & $42: 50$ & 48 & $18: 55$ & 40 \\
\hline 4 & 9 & $65: 55$ & $24: 05$ & 27 & $21: 50$ & 33 \\
\hline 5 & 9 & $84: 40$ & $06: 00$ & 7 & $12: 10$ & 14 \\
\hline
\end{tabular}

\section{Conclusions and final remarks}

The focus of this paper was the ground crew scheduling process at a small airport in the city of Niš (Serbia). Inflexibility of staff management with regard to different numbers of passengers by flight is detected as one of the focal problems of the airport processes. Limited capacities were not deployed in accordance with variable demand. The schedule for stewards was universal and consequently the system performance depended on the number of passengers. Subsequently, the problem of long queues arises, as well as wasting employees' time on flights with a small number of passengers.

In order to solve the problem, the authors developed a mathematical model implemented as the spreadsheet simulation model. Entry of flight schedules input data is realized through Microsoft Excel forms. Generic data is derived from the system and incorporated in the spreadsheet template. This data is rarely changed. Since the topic of this research was the control model for ground crew scheduling problem at small airports, spreadsheet is chosen as a tool, which requires no significant resources. Spreadsheet applications are widely accepted, flexible and easy to use without the need for complex trainings. The developed spreadsheet model facilitates understanding of the scheduling process and enables solving largerscale problems. The understanding is further supported through visualization of constraints and of model behaviour caused by change in parameters, and by the incorporated UDFs.
Numerical results of experiments conducted for a different number of flights show that feasible solutions can be generated for 3 and 4 flights, and that an increased number of flights implies the reduction of lost hours. Based on a detailed analysis of unfeasible solutions generated for 5 flights (Table 8), it can be concluded that violation of maximum working time and minimum duration of break constraints is only 20 and $10 \mathrm{~min}$, respectively. Authors of the paper propose time and motion study for the described activities to reduce their duration in order to make the instance of 5 flights feasible. Consequently, the airport management should make schedules for 5 flights per day, which requires 9 stewards. In the case of more than 5 flights per day, from the aspect of stewards' time utilization, the most cost-effective is another 5 flights and a completely new shift of 9 stewards.

\section{Disclosure statement}

Authors of the paper do not have any competing financial, professional, or personal interests from other parties.

\section{References}

Bach, L.; Dollevoet, T.; Huisman, D. 2016. Integrating timetabling and crew scheduling at a freight railway operator, Transportation Science 50(3): 878-891.

https://doi.org/10.1287/trsc.2015.0648

Bazargan, M. 2010. Airline Operations and Scheduling. Routledge. 302 p. https://doi.org/10.4324/9781315566474 
Boyer, V.; Ibarra-Rojas, O. J.; Ríos-Solís, Y. Á. 2018. Vehicle and crew scheduling for flexible bus transportation systems, Transportation Research Part B: Methodological 112: 216-229. https://doi.org/10.1016/j.trb.2018.04.008

Brusco, M. J.; Jacobs, L. W.; Bongiorno, R. J.; Lyons, D. V.; Tang, B. 1995. Improving personnel scheduling at airline stations, $O p$ erations Research 43(5): 741-751.

https://doi.org/10.1287/opre.43.5.741

Chu, S. C. K. 2007. Generating, scheduling and rostering of shift crew-duties: applications at the Hong Kong International Airport, European Journal of Operational Research 177(3): 1764-1778. https://doi.org/10.1016/j.ejor.2005.10.008

Clausen, T. 2010. Airport Ground Staff Scheduling. PhD Thesis. Technical University of Denmark, Kongens Lyngby, Denmark. 231 p. Available from Internet: https://orbit.dtu.dk/en/ publications/airport-ground-staff-scheduling

Duque, P. A. M.; Dolinskaya, I. S.; Sörensen, K. 2016. Network repair crew scheduling and routing for emergency relief distribution problem, European Journal of Operational Research 248(1): 272-285. https://doi.org/10.1016/j.ejor.2015.06.026

Giachetti, R. E.; Damodaran, P.; Mestry, S.; Prada, C. 2013. Optimization-based decision support system for crew scheduling in the cruise industry, Computers \& Industrial Engineering 64(1): 500-510. https://doi.org/10.1016/j.cie.2012.08.011

Herbers, J. 2005. Models and Algorithms for Ground Staff Scheduling on Airports. Doctoral Dissertation. RWTH Aachen University, Aachen, Germany. 259 p. Available from Internet: http://publications.rwth-aachen.de/record/59558

IATA. 2019. International Air Transport Association. Available from Internet: https://www.iata.org

ICAO. 2019. International Civil Aviation Organization. Available from Internet: https://www.icao.int

Ivković, I.; Čokorilo, O.; Kaplanović, S. 2018. The estimation of GHG emission costs in road and air transport sector: case study of Serbia, Transport 33(1): 260-267. https://doi.org/10.3846/16484142.2016.1169557

Kasirzadeh, A.; Saddoune, M.; Soumis, F. 2017. Airline crew scheduling: models, algorithms, and data sets, EURO Journal on Transportation and Logistics 6(2): 111-137. https://doi.org/10.1007/s13676-015-0080-x

NCGA. 2019. Statistics. Niš Constantine the Great Airport (NCGA), Serbia. Available from Internet: http://nis-airport.com/en/traffic-figures

Oketch, C. A. 2013. Algorithm Optimization for Solving Crew Scheduling Problems. MSc Thesis. Open University of Catalonia, Barcelona, Catalonia, Spain. Available from Internet: http://hdl.handle.net/10609/19179

Pavlin, S.; Dimnik, I.; Starčević, M. 2007. Influence of low-cost carriers on airport infrastructure development, Promet Traffic \& Transportation 19(1): 49-54.

Pour, S. M.; Drake, J. H.; Ejlertsen, L. S.; Rasmussen, K. M.; Burke, E. K. 2018. A hybrid Constraint Programming/Mixed Integer Programming framework for the preventive signaling maintenance crew scheduling problem, European Journal of Operational Research 269(1): 341-352. https://doi.org/10.1016/j.ejor.2017.08.033

Rodič, B.; Baggia, A. 2017. Airport ground crew scheduling using heuristics and simulation, in M. Mujica Mota, I. Flores De La Mota (Eds.). Applied Simulation and Optimization: New Applications in Logistics, Industrial and Aeronautical Practice, 131-160. https://doi.org/10.1007/978-3-319-55810-3_5

Santosa, B.; Sunarto, A.; Rahman, A. 2010. Using differential evolution method to solve crew rostering problem, Applied Mathematics 1(4): 316-325. https://doi.org/10.4236/am.2010.14042
Soukour, A. A.; Devendeville, L.; Lucet, C.; Moukrim, A. 2013. A memetic algorithm for staff scheduling problem in airport security service, Expert Systems with Applications 40(18): 7504-7512. https://doi.org/10.1016/j.eswa.2013.06.073

Wang, Y.; Shang, Z.; Huisman, D.; D’Ariano, A.; Zhang, J. C. 2018. A Lagrangian Relaxation Approach Based on a TimeSpace-State Network for Railway Crew Scheduling. Econometric Institute Report EI2018-45. Erasmus University Rotterdam, The Netherlands. 24 p. Available from Internet: https://repub.eur.nl/pub/114114

Yen, J. W.; Birge, J. R. 2006. A stochastic programming approach to the airline crew scheduling problem, Transportation Science 40(1): 3-14. https://doi.org/10.1287/trsc.1050.0138

Zhou, W.; Yang, X.; Deng, L.; Qin, J. 2016. Crew scheduling considering both crew duty time difference and cost on urban rail system, Promet - Traffic \& Transportation 28(5): 449-460. https://doi.org/10.7307/ptt.v28i5.1842 